\title{
EFFECT OF GREENHOUSE NIGHT HEATING BY SOLAR ENERGY SYSTEM AND ORGANIC FERTILIZER ON THE PRODUCTIVITY OF TOMATO
}

\author{
T.R. Yakout ${ }^{1}$ and S.G. Hemada ${ }^{2}$
}

ABSTRACT

The aim of this experimental work was to investigate the effect of utilizing different rates of dried biogas digester residue as organic fertilizer and solar energy for heating greenhouse on growth, development, productivity, and fruit quality of tomato hybrid (Agiad 7) during winter of two following growing seasons (2013 and 2014). Two similar gable-evenspan greenhouses were functioned at EL-Sabahia Horticultural Research Station. The seedlings of tomato hybrid Agiad 7 were planted on the $1^{\text {st }}$ week of December during the two growing seasons under two different greenhouse microclimates. The first greenhouse (GH1) was equipped with a complete heating system utilizing the solar energy, while, the second greenhouse (GH2) was mechanically ventilated during daylight without heating system.

Referring to the effect of the solar heating system on the greenhouse microclimate, the obtained results revealed that, the maximum and minimum indoor air temperatures of greenhouse (GH1) were (24.3 and 11.6), (26.0 and 12.1), (28.1 and 15.2), (28.6 and 16.3) and (30.6 and 17.1) ${ }^{\circ} \mathrm{C}$ during the experimental period (from December to April), respectively. On the other hand, the maximum and minimum indoor air temperatures of the greenhouse (GH2) were (25.3 and 6.0), (26.8 and 6.3), (28.0 and 10.8), (29.8 and 13.4) and (32.6 and 15.3) ${ }^{\circ} \mathrm{C}$ during the same period, respectively. Referring to the effect of organic fertilizer rates on the tomato plant vegetative growth, showed that increasing the organic fertilizer rate significantly increased all the studied characters; plant length, leaf area, number of leaves per plant, dry weight and stem diameter in both seasons whereas, the fresh weight increase was not significant in 2014 season.

\footnotetext{
${ }^{1}$ Researcher, Protected Cultivation Res. Dept., Horticultural Research Institute, ARC, Giza, Egypt.

${ }^{2}$ Researcher, Power and Energy Res. Dept., Agricultural Engineering Research Institute, ARC, Giza, Egypt.
} 
The data also, showed that plants fertilized with $30 \mathrm{~m}^{3} / \mathrm{fed}$ from dried biogas residue gave the best vegetative growth characteristics; plant height, leaf area, fresh, dry weight per plant and stem diameter as compared with other used organic levels in both seasons. Early yield, number of fruit per plant, fruit weight, total yield per plant and total yield per feddan were significantly increased by increasing the organic fertilizer rate in both 2013 and 2014 seasons.

For the heated greenhouse (GH1), the percentages increase in early yield, number of fruit per plant, fruit weight, total yield per plant and total yield per feddan were 28.64, 13.04, 6.89, 20.84 and 20.84\%, respectively for dried biogas residue of $30 \mathrm{~m}^{3} /$ fed over those of farm yard manure, respectively in 2013 season. For the unheated greenhouse (GH2), the percentages increase in early yield, number of fruit per plant, fruit weight, total yield per plant and total yield per feddan over those of farm yard manure were 13.18, 16.29, 8.30, 25.52 and 25.52\%, respectively for $30 \mathrm{~m}^{3} /$ fed dried biogas residues in same season. Whereas, in the second season 2014, for the heated greenhouse (GH1), the percentages increase in early yield, number of fruit per plant, fruit weight, total yield per plant and total yield per feddan over those of farm yard manure were 24.87, 11.18, 6.89, 18.86 and 18.86\%, respectively for $30 \mathrm{~m}^{3} / \mathrm{fed}$ dried biogas residue, respectively. For the unheated greenhouse (GH2), the percentages increase in early yield, number of fruit per plant, fruit weight, total yield per plant and total yield per feddan over those of farm yard manure were 17.18, 16.29, 5.87, 22.84 and $22.84 \%$, respectively for $30 \mathrm{~m}^{3} / \mathrm{fed}$ dried biogas residues in same season.

Concerning effect of the microclimatic conditions of (GH1) it was at and around the optimal level for the tomato crop, resulting in increase the tomato growth, development, and productivity. The percentages increase for greenhouse GH1 over GH2 greenhouse in early yield, number of fruit per plant, fruit weight, total yield per plant and total yield per feddan were $21.32,17.42,12.87,32.28$ and $32.28 \%$, respectively, in 2013 season while, they were 16.06, 15.33,10.14, 27.08 and 27.08\%, respectively in 2014 season. 


\section{INTRODUCTION}

I

$\mathrm{n}$ the winter period, the temperature under greenhouse is very low at night and it is rather high during the day. Consequently, the night heating of greenhouse is essential, Lazâar et al. (2008). Heating greenhouses in cold climate is usually performed by burning non renewable fossil fuel, generally oil. The environmental benefits of consuming vegetables locally grown in greenhouses that involve less transportation can be canceled by the large amount of energy required to grow those vegetables in greenhouses in winter. Therefore, different strategies have been considered to reduce energy consumption in greenhouses. Using solar energy to heat greenhouses is one of prime importance. With a high glazed surface area, greenhouses are natural solar collectors. Increasing thermal mass and insulation is necessary to keep the solar energy inside to heat the greenhouse at night, Santamouris et al. (1994).

Fertilizer is an organic or inorganic material, containing one or more essential nutrients, which is used to provide nutrients for the growth of crops and increasing productivity and quality of agricultural products, (Zhang et al., 2010). Nemours researchers reported the importance of fertilizers in enhancing crop production. Firstly, they make crop plants grow and develop better and achieve high productivity. Fertilizers give vigorous plants and increase vegetative growth such as; plant height, quantity, and length of plant stem, leaf area, and leaf chlorophyll on many kinds of crop (Chapagain and Wiesman, 2004; Wang et al., 2007; Najm et al., 2010; Zafar et al., 2011; Aminifard et al., 2012; Yakout et al., 2014). Secondly, using fertilizers increases crop productivity (Heeb et al., 2006; Riahi et al., 2009; Aminifard at el., 2012; Yang et al., 2012; Çolpan et al., 2013). According to statistics of Food and Agriculture Organization of the United Nations (FAO, 1981), fertilizers help to increase 40-60\% of crop yields (FAO, 1981; Zhang et al., 2010). Thirdly, fertilizers improves the quality of fruits such as vitamin, organic acid, mineral contents, dry matter content, etc. (Pirkko et al. 2003; Kobryn and Hallmann, 2005; Zaller, 2006; Dursun et al., 2009; Cesare et al., 2010; Junior et al., 2013).

Adding organic manures to soil would improve their physical-chemical and biological properties which increase soil organic matter, cation 
exchange capacity, available mineral nutrition (Mervat et al., 1995) and this in turn stimulate quantitative as well as qualitative characteristics of vegetable crops. The use of organic matters such as animal manures, human waste, food wastes, yard wastes and composts has long been recognized in agriculture as beneficial for plant growth and yield, also, soil fertility. (Joshi and pal Vig, 2010). Many workers pointed out the valuable role of organic manures to stimulate plant growth, yield of vegetables among them Abdalla et al. (2001), Yakout et al., (2014), on pepper; Abou-Hussein et al., (2002) on potatoes; Adam et al., (2002) on cantaloupe; Rizk et al., (2003) on squash and El-Araby (2004), ElGamal and Hammed (2005) and Hamed (2008) on Jerusalem artichoke. Tomato (Lycopersicon esculentum Mill.) belongs to the family Solanaceae and is an important vegetable crop all over the world. It is used in numerous forms, such as fresh salad, cooked foods and in processed forms like ketchup, paste etc., it is known as a favorite vegetable crop, rich in vitamins and minerals for human. In Egypt, the late summer market tomato crop is yielded from transplants planted into the open field during April up to June. During this period, temperature can exceed $35^{\circ} \mathrm{C}$ under field condition resulting in either non-uniform growth and poor fruit yield or even completely failure of tomato cropping in a great part of the cultivated area, (Pressman et al., 2002; Adil et al., 2004). With regard to the effect of temperature on growth and productivity of tomato plants, Saeed $\boldsymbol{e t}$ al. (2007) whose found that high temperatures during the growing season have been reported to be detrimental to growth, reproductive development and yield of several crops. In tomato high temperature during reproductive development caused significant increment in flower drop and significant decrease in fruit set and consequently fruit yield was decreased to a great extent. At high temperature, the reproductive part of the flower is adversely affected. Stigma tube elongation, poor pollen germination, poor pollen tube growth and carbohydrate stress are the main reasons for poor fruit set at high temperature in tomato, Vollenweider and Gunthardt-Goerg (2005). Furthermore, Sato et al. (2000) reported that under high temperatures, fruit set in tomato plants failed due to disruption of sugar metabolism and transport during the narrow window of male reproductive development. Moreover, Heat stress is a major factor that restricts tomato 
production during summer season in the Sudan. High temperature harmfully affects plant growth and survival and hence crop yield (Abd El-Mageed and Gruda, 2009).

Temperature is the most important climatic factor to be considered in vegetable production. It determines when and where a certain crop can be grown, and vegetable crops can be broadly classified according to their temperature requirements. In this respect, Tomato can be classified as warm season crops which very sensitive to the low temperature (Tender, sensitive to frost and low temperature)). It is known that the mean monthly temperatures for tomato are: optimum, $18-24^{\circ} \mathrm{C}$; maximum; $27^{\circ} \mathrm{C}$ and the minimum $18^{\circ} \mathrm{C}$, (climatic-requirements.pdf). The higher average temperature causes an increased rate of crop development and is responsible for earlier fruit maturation (Pardossi et al., 2000).

Youssef (2007) developed two mathematical simulation computer programs to achieve the optimal combination of various designated parameters required for sizing a solar thermal water storage system. The experimental data revealed that the thermal storage system operated satisfactorily for six months without malfunction for keeping the greenhouse indoor air temperature at or around the optimal level throughout the day for cucumber crop. Also, Youssef and Moussa (2015) stated they were utilized solar energy for heating greenhouse and studied its effect on growth, development, productivity, and fruit quality of three different hybrid of sweet melon crop. The obtained data showed that, the microclimatic conditions of solar heated greenhouse was at and around the optimal level for the sweet melon crop, resulting in increase the growth, development, and productivity of crop. The increase percentages in fruit yield were 18.35 and $27.59 \%$ over the un-heated greenhouse in the first and second season, respectively.

The objectives of this study were to; 1) utilizing the solar energy for night heating the greenhouse indoor air and conserve energy, 2) reduce the indoor temperature fluctuation of the greenhouse by elevating the nighttime indoor air temperature of greenhouse, 3) studying the effect of applying the night heating and different rates of organic fertilizer (dried biogas digester residue) on tomato growth, development, productivity and fruit quality. 


\section{MATERIALS AND METHODS}

\subsection{Materials}

Two identical gable-even-span greenhouses were utilized at EL-Sabahia Horticultural Research Station (latitude and longitude angles, respectively, are $31.22{ }^{\circ} \mathrm{N}$ and $30.50^{\circ} \mathrm{E}$ ), Alexandria Governorate, to grow and produce tomato (Agiad 7 hybrid) during winter season of two successive growing seasons (2013 and 2014). The geometric characteristics of each greenhouse are as follows: eaves height $2.93 \mathrm{~m}$, height of each side wall $2 \mathrm{~m}$, rafter angle $25^{\circ}$, width $4 \mathrm{~m}$, length $8 \mathrm{~m}$, floor surface area $32 \mathrm{~m}^{2}$, and volume $78.922 \mathrm{~m}^{3}$. The two greenhouses (GH1 and $\mathrm{GH} 2$ ) are covered using single layer of polyethylene sheet (PE) of $200 \mu \mathrm{m}$ as shown in Fig. (1).

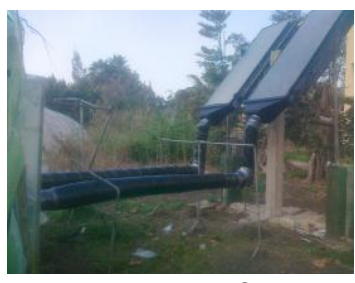

a- Two solar collectors for heating GH1

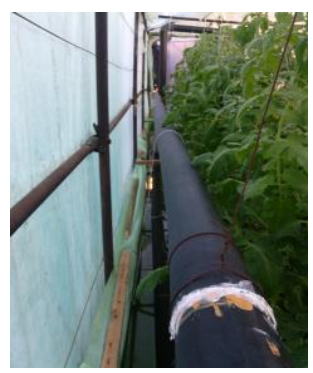

c- Left thermal storage tank

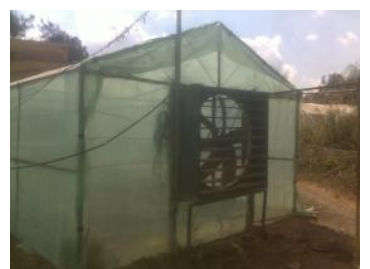

b- Mechanically ventilated greenhouse (GH2)

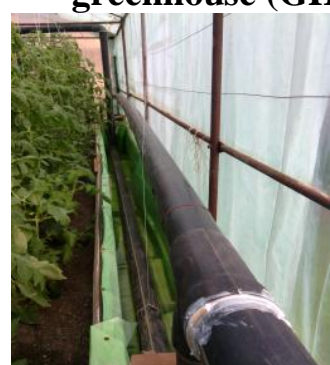

d- Right thermal storage tank

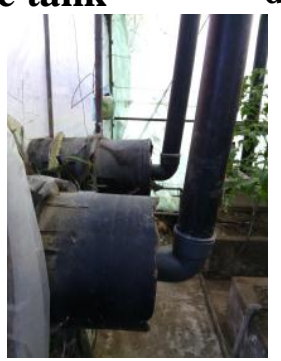

e - Two suction fans

Fig. (1): Experimental gable-even-span greenhouses and the solar heating system. 
Two solar collectors, each has the dimension of $3.0 \times 1.0 \mathrm{~m}$, and they were fixed on concrete foundation facing south. The solar collectors monthly optimum tilt angles were manually oriented to collect as much as solar radiation incident, (Fig, 1-a), and they were connected to two extracting fans inside the greenhouse (GH1), (Fig, 1-e). Two wooden thermal storage water tanks were constructed in both sides of the greenhouse, (Fig, $1 \mathrm{c}$ and d). Each has the dimensions of $6.0 \times 0.35 \times 0.5 \mathrm{~m}$. An air-towater heat exchanger was constructed in each thermal storage water tanks. The two thermal storage water tanks were well insulated from bottom and side walls to prevent heat losses and coated with black plastic to absorb as much as solar energy. The net volume of water in each thermal storage tank was $0.86 \mathrm{~m}^{3}$. The other greenhouse (GH2) was mechanically ventilated during daylight only (Control) as shown in Fig, (1b).

Tomato hybrid (Agiad 7) was utilized to investigate the effects of different macroclimatic conditions and organic fertilizer rates on plant vegetative growth and fruit yield and quality. Two vegetative trays (84 growth blocks) were used to germinate the seeds of tomato plant. Seeds were sown in the nursery on $2^{\text {nd }}$ week of October in 2013 and 2014. Seedling transplant was performed on $1^{\text {st }}$ week of December in 2013 and 2014 seasons. Planting distance was $50 \mathrm{~cm}$ apart. Each plot has 14 plants of the used tomato hybrid. The experimental treatments were two greenhouses, (GH1 and $\mathrm{GH} 2$ greenhouses); three rates of organic fertilizer; (30, 20 and $10 \mathrm{~m}^{3} / \mathrm{fed}$ ) compared with the control (farm yard manure $20 \mathrm{~m}^{3} / \mathrm{fed}$ ). As well as, chemical fertilizers were added according to the recommended doses provided by Ministry of Agriculture and Land Reclamation (2004) of NPK liquid commercial fertilizer, each week during the whole season through the drip irrigation system. The microminerals; iron, copper, manganese, zinc, magnesium and born were utilized as foliar spraying. It must be mentioned that the tomato plants were pruned to one leader stem with one branch at $150 \mathrm{~cm}$ height on the leader stem. The experimental design was a split plot design with three replicates; the experiment included eight treatments which were as follows: 
$\mathrm{T}_{1}: \quad \mathrm{GH} 1+30 \mathrm{~m}^{3} /$ fed organic fertilizer (OR30)

$\mathrm{T}_{2}: \quad \mathrm{GH} 1+20 \mathrm{~m}^{3} /$ fed organic fertilizer (OR20)

$\mathrm{T}_{3}: \quad \mathrm{GH} 1+10 \mathrm{~m}^{3} /$ fed organic fertilizer (OR10)

$\mathrm{T}_{4}: \quad \mathrm{GH} 1+20 \mathrm{~m}^{3} /$ fed $(\mathrm{FYM})$

$\mathrm{T}_{5}: \mathrm{GH} 2+30 \mathrm{~m}^{3} /$ fed organic fertilizer (OR30)

$\mathrm{T}_{6}: \quad \mathrm{GH} 2+20 \mathrm{~m}^{3} /$ fed organic fertilizer (OR20)

$\mathrm{T}_{7}: \mathrm{GH} 2+10 \mathrm{~m}^{3} /$ fed organic fertilizer (OR10)

$\mathrm{T}_{8}: \quad \mathrm{GH} 2+20 \mathrm{~m}^{3} /$ fed $(\mathrm{FYM})$

The organic fertilizer (dried biogas digester residue) was the bi-product of biogas production digesters supplied by "Development of Biogas Production and Utilization Systems Project" which financially supported by the Agricultural Development Program (ADP) and Implemented at the Tractors and Machinery Research and Test Station, Alexandria city, Agricultural Engineering Research Institute. The physic-chemical properties of the organic fertilizers are shown in Table (1) and the soil samples analysis is shown in Table (2). The percentage of total nitrogen $(\mathrm{N})$, total phosphorus $(\mathrm{P})$, total potassium $(\mathrm{K})$ was calculated from their relative contents in $100 \mathrm{~g}$ dry samples.

Table (1). Physic-chemical properties of the two organic fertilizers.

\begin{tabular}{|c|c|c|c|}
\hline Items & Unit & $\begin{array}{c}\text { Dried biogas } \\
\text { residue }\end{array}$ & Farm yard manure \\
\hline $\mathrm{N}$ & $\%$ & 5.01 & 1.06 \\
\hline $\mathrm{P}$ & $\%$ & 5 & 1.8 \\
\hline $\mathrm{K}$ & $\%$ & 5.41 & 1.2 \\
\hline $\mathrm{Fe}$ & $\mathrm{Meq} / \mathrm{L}$ & 868 & 383 \\
\hline $\mathrm{Zn}$ & $\mathrm{Meq} / \mathrm{L}$ & 74 & 76 \\
\hline $\mathrm{Cu}$ & $\mathrm{Meq} / \mathrm{L}$ & 60 & 20 \\
\hline $\mathrm{Cd}$ & $\mathrm{Meq} / \mathrm{L}$ & 16 & 18 \\
\hline $\mathrm{Ni}$ & $\mathrm{Meq} / \mathrm{L}$ & 184 & 0 \\
\hline $\mathrm{Cr}$ & $\mathrm{Meq} / \mathrm{L}$ & 0 & 96 \\
\hline $\mathrm{Pb}$ & $\mathrm{Meq} / \mathrm{L}$ & 54 & \\
\hline
\end{tabular}

In order to conserve the energy, the ventilation system of the heated greenhouse was acted differently throughout the 24 hours. It was activated and the fans were switched $\mathrm{ON}$ during daylight-time from sunrise to sunset to grasp the solar radiation energy from the solar 
collectors and delivered it to the water of the thermal storage tanks through the constructed air to water heat exchangers inside the water tanks. During this period, the warm air releases its heat on the thermal storage water tank. The greenhouse air also, was warmed up by the transmitted incident solar radiation through the greenhouse cover (The greenhouse considers as a huge solar collector). Meanwhile, the indoor air temperature of the greenhouse during daylight-time could dramatically increase over the set point temperature, $\left(27.0^{\circ} \mathrm{C}\right)$. This air also, exchanged heat with the water in the tanks by convection. In addition, the solar radiation was directly incident on the surface of the water of the thermal storage system. These are three sources for heating the water inside the thermal storage tanks.

Table (2). Characteristics of the soil samples.

\begin{tabular}{|c|c|c|c|}
\hline Items & Unit & Season 2013 & Season 2014 \\
\hline Clay & $\%$ & 45.2 & 39.5 \\
\hline Silt & $\%$ & 35.1 & 37.2 \\
\hline Sand & $\%$ & 21.8 & 23.4 \\
\hline Organic matter & $\%$ & 22.4 & 25.7 \\
\hline Soil texture & ---- & Clay loam & Clay loam \\
\hline $\mathrm{pH}^{*}$ & ---- & 7.6 & 7.7 \\
\hline $\mathrm{EC}^{* *}$ & $\mathrm{dSm}^{-1}$ & 3.35 & 3.32 \\
\hline \multicolumn{4}{|l|}{$\underline{\text { Soluble cations }}$} \\
\hline $\mathrm{Ca}^{++}$ & $\mathrm{Meq} / \mathrm{L}$ & 3.8 & 4.6 \\
\hline $\mathrm{Mg}^{+}$ & $\mathrm{Meq} / \mathrm{L}$ & 3.6 & 2.9 \\
\hline $\mathrm{K}^{+}$ & $\mathrm{Meq} / \mathrm{L}$ & 21 & 19 \\
\hline $\mathrm{Na}$ & $\mathrm{Meq} / \mathrm{L}$ & 7.2 & 7.4 \\
\hline \multicolumn{4}{|l|}{ Soluble anions } \\
\hline $\mathrm{CO}_{3}^{--}$ & $\mathrm{Meq} / \mathrm{L}$ & 3.1 & 3.3 \\
\hline $\mathrm{HCO}_{3}^{-}$ & $\mathrm{Meq} / \mathrm{L}$ & 1.7 & 1.9 \\
\hline $\mathrm{Cl}^{-}$ & $\mathrm{Meq} / \mathrm{L}$ & 5.5 & 5.6 \\
\hline $\mathrm{SO}_{2}^{--}$ & $\mathrm{Meq} / \mathrm{L}$ & 2.9 & 3.2 \\
\hline Total $\mathrm{N}$ & $\%$ & 0.18 & 0.19 \\
\hline Available phosphorus & & 30.9 & 30.7 \\
\hline
\end{tabular}

* measured in 1:25 soil water suspension.

** measured in the water extract of saturation soil paste. 
A digital thermostat controller for the fans operation was adjusted at a set point temperature during the daylight and nighttime. At night the gates between the solar collectors and fans were closed and other gates facing the inside greenhouse air were opened. Hence, when the greenhouse indoor air temperature started to decline below the minimum set point, the fans were automatically switched ON again. During this period from midnight until sunrise next day, intermittent ventilation was carried out and the stored heat in the thermal storage water tanks was absorbed once again by the air and was restored back to warm up the indoor air of greenhouse. This was to prevent the greenhouse interior air temperature from dropping below the desired temperature at night.

\subsection{Environmental measurements}

The measurements were employed from December to April of both 2013 and 2014 seasons. The meteorological data from a meteorological station (5 KUE SKH 2013) were used to measure solar radiation flux incident on a horizontal surface (Pyranometer), dry-bulb air temperature (ventilated thermistor), wind speed and its direction (cup anemometer and wind vane), and air relative humidity (hygrometer) outside the greenhouses. The data were collected and sent through the network of the Central Laboratory for Agricultural Climate (CLAC), Dokki, ARC. The indoor air temperatures and relative humidities at middle of both greenhouses were measured and recorded using two Data-loggers type SATO, SKL200 II- Japan, temperatures of entering air of the solar collectors and water temperatures in the thermal storage tanks were recorded using thermocouple sensors type $\mathrm{K}$. These sensors were connected to digital multimeter record the data throughout the experimental work.

\subsection{Vegetative measurements}

Random samples of five plants from each replicate were taken after 120 days from transplanting to record the following characters:-

\subsubsection{Vegetative growth characteristics}

2.3.1.1 Plant height $(\mathrm{cm})$.

2.3.1.2 Leaf area $\left(\mathrm{cm}^{2}\right)$ was measured of the $5^{\text {th }}$ true leaf by using laser leaf area meter.

2.3.2 Number of leaves per plant.

2.3.4 Plant dry weight (gm) plant sample was dried at $70{ }^{\circ} \mathrm{C}$.

2.3.5 Stem diameter. 


\subsection{Chemical composition}

Sample of the fourth top leaves were dried at $70{ }^{\circ} \mathrm{C}$ till constant weight and wet digested to determine N, P and $\mathrm{K}$ contents as follows:-.

2.4.1 Total nitrogen (\%) in leaves was determined by using Microkjeldahil by A.O.C.A., (1990).

2.4.2 Phosphorus (\%) was determined calorimetrically at $550 \mathrm{~mm}$ as described by Ranganna, (1979).

2.4.3 Potassium (\%) was determined by flame photometer as described by Ranganna (1979).

2.4.4 Micro nutrients Fe and Mn contents were determined for the above ground dried vegetative parts by using atomic spectrophotometer according to Chapman and pratt, (1981).

2.4.5 Total soluble solids (TSS) \% of fruit was measured by refractometer.

2.4.6 Total Acidity was determined as $\mathrm{mg} / 100 \mathrm{ml}$ juice (mg/100 g f.w.)

by using $\mathrm{NaOH}$ with phenolphthalein as indicator is mentioned by A.O.C.A. (1980).

2.4.7 Total chlorophyll content was determined in sample taken randomly from the fourth upper leaf according to A.O.A.C., (1990).

2.4.8 Vitamin C content (ascorbic acid) was determined as $\mathrm{mg} / 100 \mathrm{ml}$ juice $(\mathrm{mg} / 100 \mathrm{~g} \mathrm{f}$. w.) by using the 2,6 dichloro phenol indophenols method, (A.O.C.A., 1980).

\subsection{Fruit physical characteristics:-}

2.5.1 Fruit length $(\mathrm{cm})$

2.5.3 Shape index (L/D)

\subsection{Yield and its components:-}

2.6.1 Early yield (kg\plant).

2.6.2 Number of fruit per plant.

2.6.5 Total yield (ton $\backslash$ feddan).

\subsection{Statistical Analysis:}

The experimental design was a split plot design with three replicates. The analysis of variance was used to analyze the obtained data as outlined by Snedecor and Cochran (1980). Comparisons among the means of different treatments were done, using least significant difference test procedure at $\mathrm{p}=0.05$ level of significance using CoStat Ver. 6.311-2005 Software packages. 


\section{RESULTS AND DISCUSSIONS}

The main thermal solar system indicators are the temperatures of water inside the thermal storage tank $\left(\mathrm{T}_{\mathrm{w}}\right)$, indoor air temperature of greenhouse $\left(\mathrm{T}_{\mathrm{ai}}\right)$ and ambient air $\left(\mathrm{T}_{\mathrm{ao}}\right)$. The set-point temperature at nighttime were 15.0, 15.0, 16.0, 18.0 and $18.0{ }^{\circ} \mathrm{C}$ for December, January, February, March and April months, respectively, to achieve an optimum night heating requirements to be used as energy conservation regime, as recommended by Youssef (2007).

\subsection{Solar radiation flux incident outside the greenhouses}

The hourly averages solar radiation flux incident on a horizontal surface outside the two greenhouses during the experimental period (from December to April) is plotted in Fig. (2). It clearly reveals that, the solar radiation flux incident was varied from month to month and from hour to another throughout the experimental period. Therefore, the daily average solar radiation flux incident outside the two greenhouses during the experimental period (from December to April) was 357.6, 389.4, 470.6, 525.6, and $636.7 \mathrm{~W} / \mathrm{m}^{2}$, respectively.

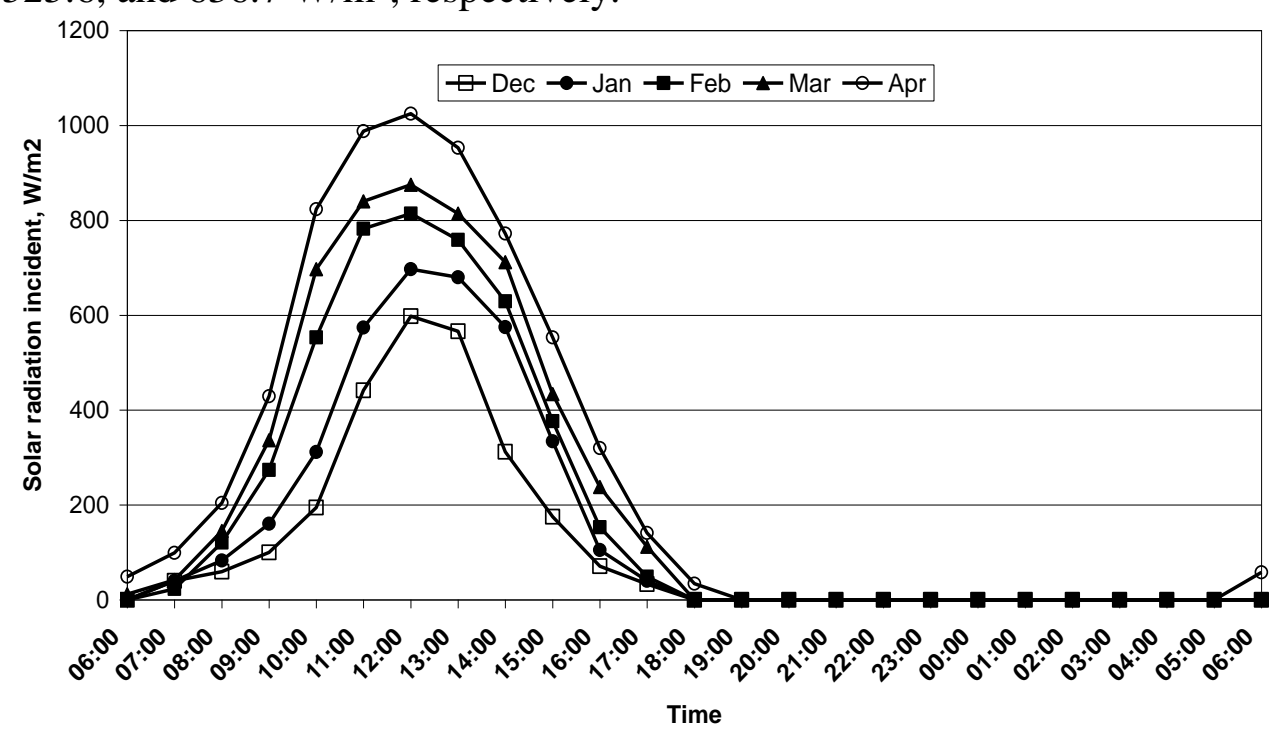

Fig. (2): Solar radiation flux incident on a horizontal surface during in the experimental period as a function of solar time.

\subsection{Temperatures of the solar heated greenhouse and its components:}

The monthly average temperatures of water, indoor air of greenhouse (GH1) and outside ambient air as affected by the solar heating system 
during the experimental period are illustrated in Fig. (3a, b, c, d, e and f). The monthly average maximum water temperatures in the storage tank were $24.8,26.2,27.8,28.8$ and $30.2^{\circ} \mathrm{C}$ which were achieved at 2:15, 3:15, 3:45, 4:15 and 4:45 pm during for December, January, February, March and April months, respectively. These results revealed that, as the solar energy fluxes incident outside the greenhouses increased the water temperatures in the storage tank were increased. Also, the achievement time were shifted towards the time of sunset, (i.e., more energy was stored in the thermal storage tank). Consequently, the percentage increase in water temperatures over December month was 105.6, 112.3, 116.4 and 121.9\% for February, March and April months, respectively.

The monthly average maximum indoor air temperatures of greenhouse (GH1) during the experimental period (from December to April), respectively, were $24.3,26.0,28.1,28.6$ and $30.6{ }^{\circ} \mathrm{C}$. On the other hand, the monthly average minimum indoor air temperature of the greenhouse at nighttime as affect by the solar heating system was 11.6, 12.1, 15.2, 16.3 and $17.1{ }^{\circ} \mathrm{C}$, respectively for the same months. The greenhouse indoor temperatures reached the minimum set-point temperature of the greenhouse at 7:00, 7:00, 8:00, 9:00 and 10:00 pm for the same months, respectively. These were the time of operating the greenhouse heating process and retrieving back the stored energy. These results mean that, stored energy inside the thermal storage tanks in greenhouse (GH1) during daylight-time prevented the indoor air temperature of the greenhouse from reaching harmful degree for tomato plants at nighttime, $\left(<10{ }^{\circ} \mathrm{C}\right)$. It was also, observed that the reduction in indoor air temperature of greenhouse (GH1) under the recommended level of air temperature, $\left(15^{\circ} \mathrm{C}\right)$ occurred only during December and January month. This could be attributed to the amount of solar radiation flux incident during these month were insufficient to provide and maintain the desired level of indoor air temperatures. However, the night monthly average indoor air temperatures during this month were around the optimal level. It must be mentioned that we could satisfied by the shortage in energy for these little hours only as energy conservation regime if it was not harmful for plant growth. 


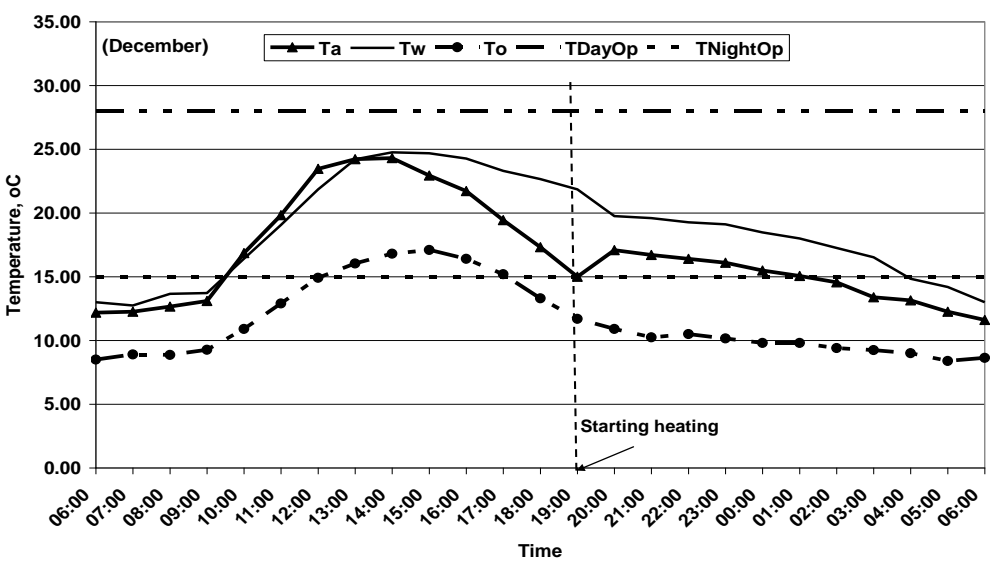

a- December

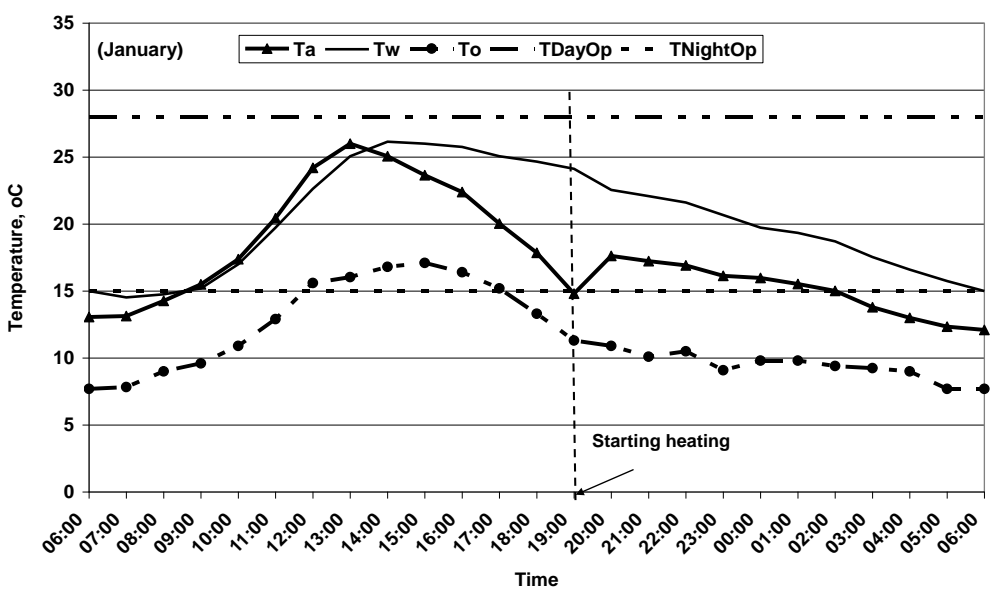

b- January

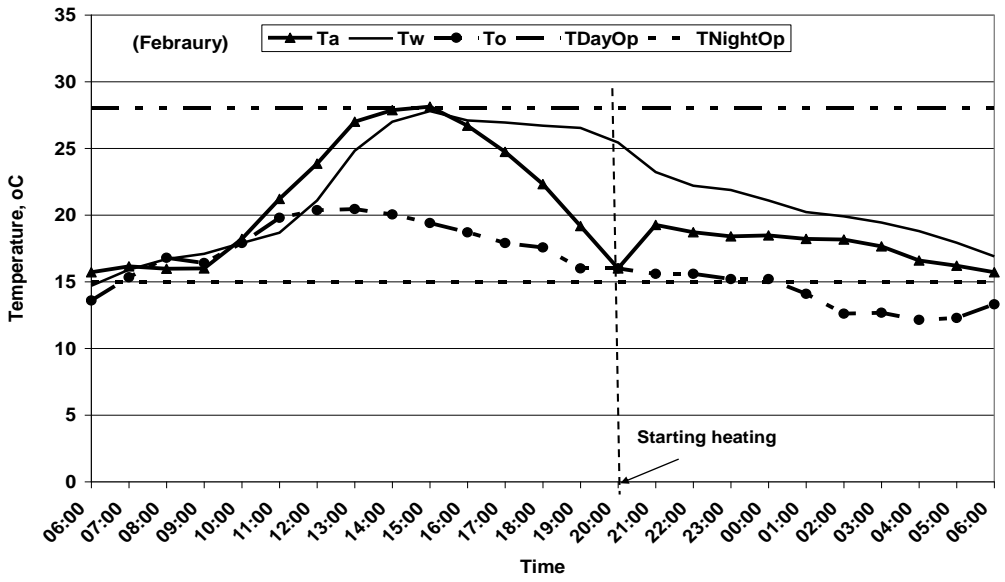

c- February 

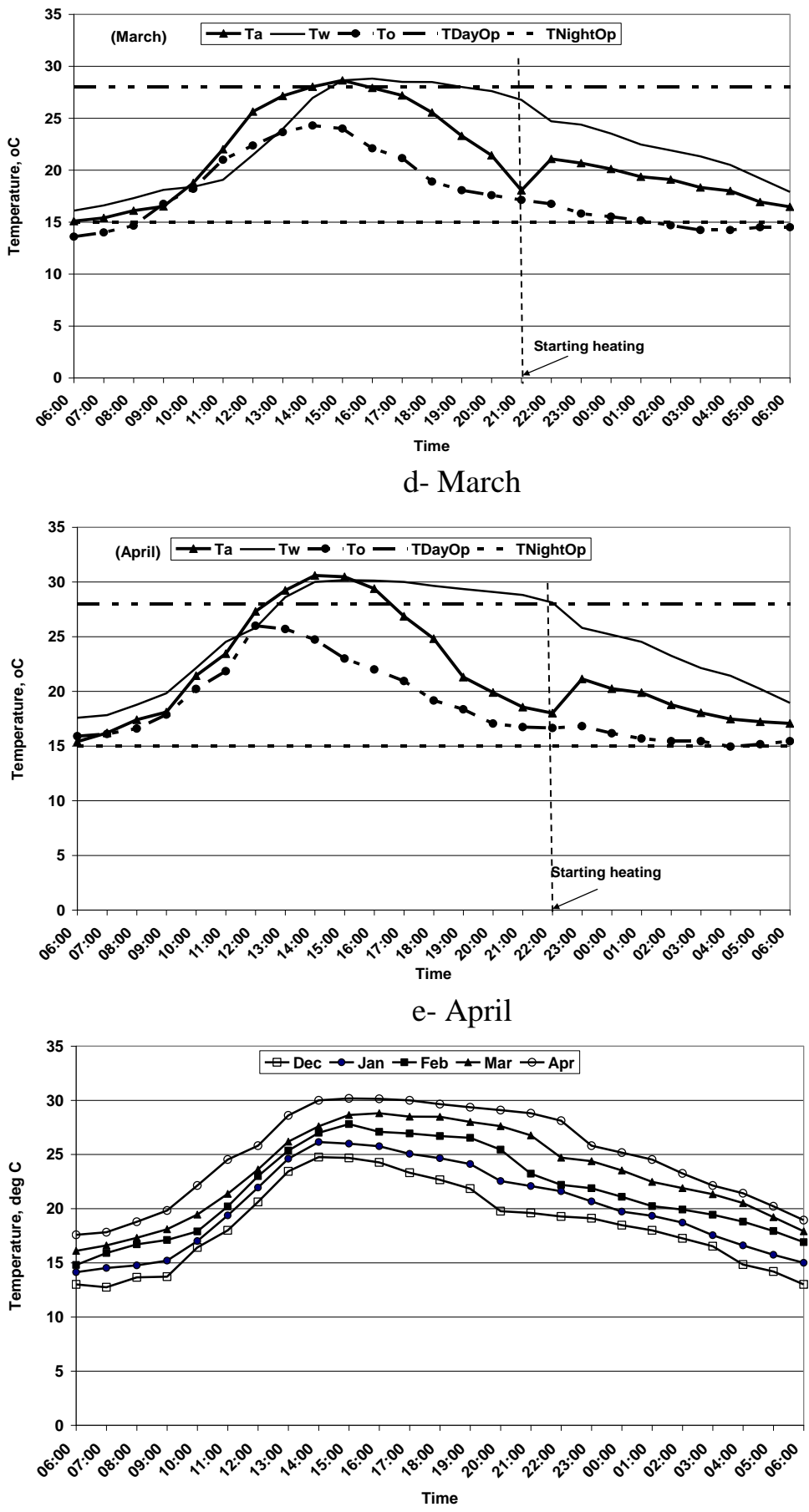

$\mathrm{f}$ - The temperatures of water in the storage tank

Fig. (3): Monthly average temperatures of water, indoor air of greenhouse (GH1) and outside ambient air during the experimental months. 


\subsection{Monthly average indoor air temperatures of the greenhouse (GH2)}

On the other side, the monthly average indoor air temperatures of the mechanically ventilated greenhouse (GH2) are plotted in Fig. (4). The monthly average maximum indoor air temperatures of the greenhouse (GH2) during the experimental period (from December to April), respectively, were $25.3,26.8,28.0,29.8$ and $32.6{ }^{\circ} \mathrm{C}$, which occurred at 1:00 pm except March month when it was recorded at 2:00 pm. On the other hand, the monthly average minimum indoor air temperature of the greenhouse (GH2) at nighttime was 6.0, 6.3, 10.8, 13.4 and $15.3{ }^{\circ} \mathrm{C}$, respectively for the same period. The greenhouse indoor temperatures reached the minimum set-point temperatures of the greenhouse at 10:00 pm, 10:00 pm, 12:00 am, 3:00 am and 10:00 pm for the December, January, February and March months, respectively. While, during April month this was not occurred. It is noticeable that the indoor temperature of mechanically ventilated greenhouse (GH2) decreased to harmful temperature $\left(<10{ }^{\circ} \mathrm{C}\right)$ during December and January months. These results revealed that the night monthly average indoor air temperatures were lower than the minimum recommended level for four months (December, January, February and March), whereas, the maximum indoor temperatures were over the maximum recommended indoor air temperatures during daylight-time occurred in March and April months.

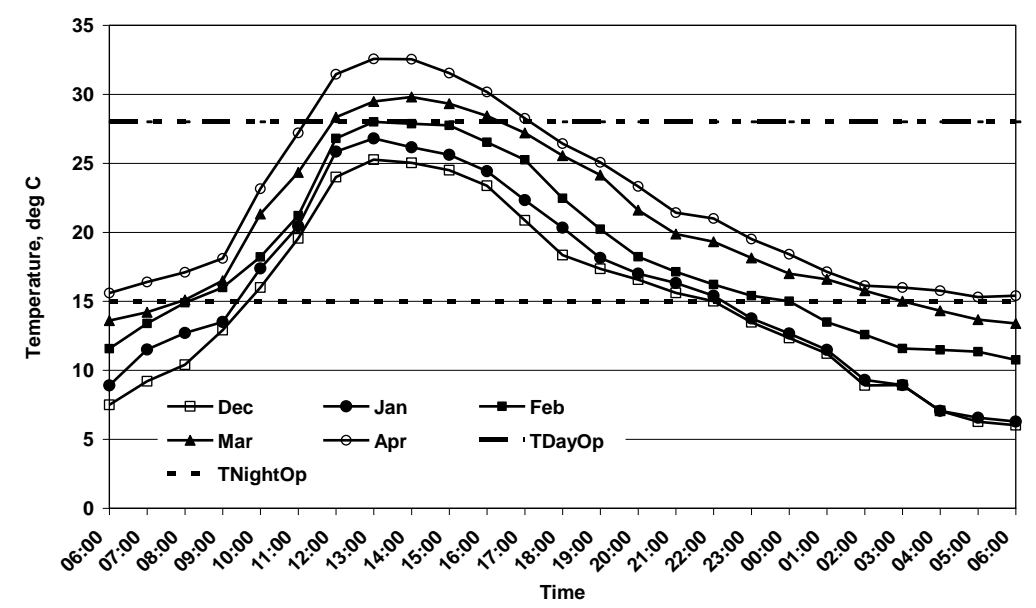

Fig. (4): Monthly average indoor air temperatures of greenhouse (GH2) during the experimental period from January to April. 
The previous two Figs (3 and 4) revealed that the fluctuations of greenhouse indoor air temperatures were higher in greenhouse (GH2) than the greenhouse (GH1). The minimum greenhouse air temperatures, (at night) also, were elevated in solar heated greenhouse, (GH1) than mechanically ventilated greenhouse, $(\mathrm{GH} 2)$. These finding can be attributed to increasing nighttime temperatures by retrieving back the stored energy in the water of the thermal storage system to worm up the greenhouse air at night for night heating. Also, the mechanically ventilation at daylight times, (at and around noon) in both March and April months could not permit the required cooling for greenhouse. These results are in agreement with that published by Youssef (2007) and Youssef and Moussa (2015) when they mentioned that night heating increased the minimum indoor air temperatures of the greenhouse and reduced the difference between the maximum and minimum greenhouse indoor air temperatures.

\subsection{Effect of greenhouse macroclimate conditions and organic fertilizer applications on vegetative growth, chemical constituents, yield and fruit quality of tomato plants}

\subsubsection{Vegetative growth of tomato plant}

Effect of the organic fertilizer treatments and macroclimate conditions on vegetative growth of tomato plants was illustrated in Table (3). The data also, showed that plants fertilized with $30 \mathrm{~m}^{3} / \mathrm{fed}$ from dried biogas residue gave the best vegetative growth characteristics; plant height, leaf area, fresh, dry weight per plant and stem diameter as compared with other used organic levels in both seasons. The $20 \mathrm{~m}^{3} / \mathrm{fed}$ came in the second rank followed by FYM, (20 $\left.\mathrm{m}^{3} / \mathrm{fed}\right)$, however $10 \mathrm{~m}^{3} / \mathrm{fed}$ application led to the lowest fresh and dry weight per plant as compared with the other organic applications. The present work showed that with respect to the superior growth of plants fertilized with dried biogas digester residue than farm yard manure could be referred to firstly, it has higher values of $\mathrm{N}, \mathrm{P}$ and $\mathrm{K}$ elements as showed in the chemical analysis of the fertilizer sample as previously shown in Table (1) secondly, biogas residue is a well fermented organic fertilizer; free of pathogen sources and seed weeds, beside the general benefits of organic-N fertilizers thus it is a good source for most macro and micronutrients and increase soil porosity 
and improve aeration of such clay loam soil of this experiment in agreement with the findings of El-Shimi (1998) and Mikhaeel, et al., (1997) who found the superiority of biogas organic fertilizer on plant growth. Also, Nguyen et al., (2015) mentioned that the applications of organic fertilizers enhanced the leaf area and average fruit weight and yield of tomato fruit. Concerning the effect of greenhouse microclimate on vegetative growth, data in Table (3) showed that the plant height, stem diameter, fresh and dry weight of greenhouse GH1 was significantly increased than those of greenhouse $\mathrm{GH} 2$. On the other hand, there was no significant difference for the leaf area and number of leaves per plant of both greenhouses in both 2013 and 2014 seasons.

Table (3). Effect of macroclimate conditions and organic applications

on vegetative growth in 2013 and 2014 seasons.

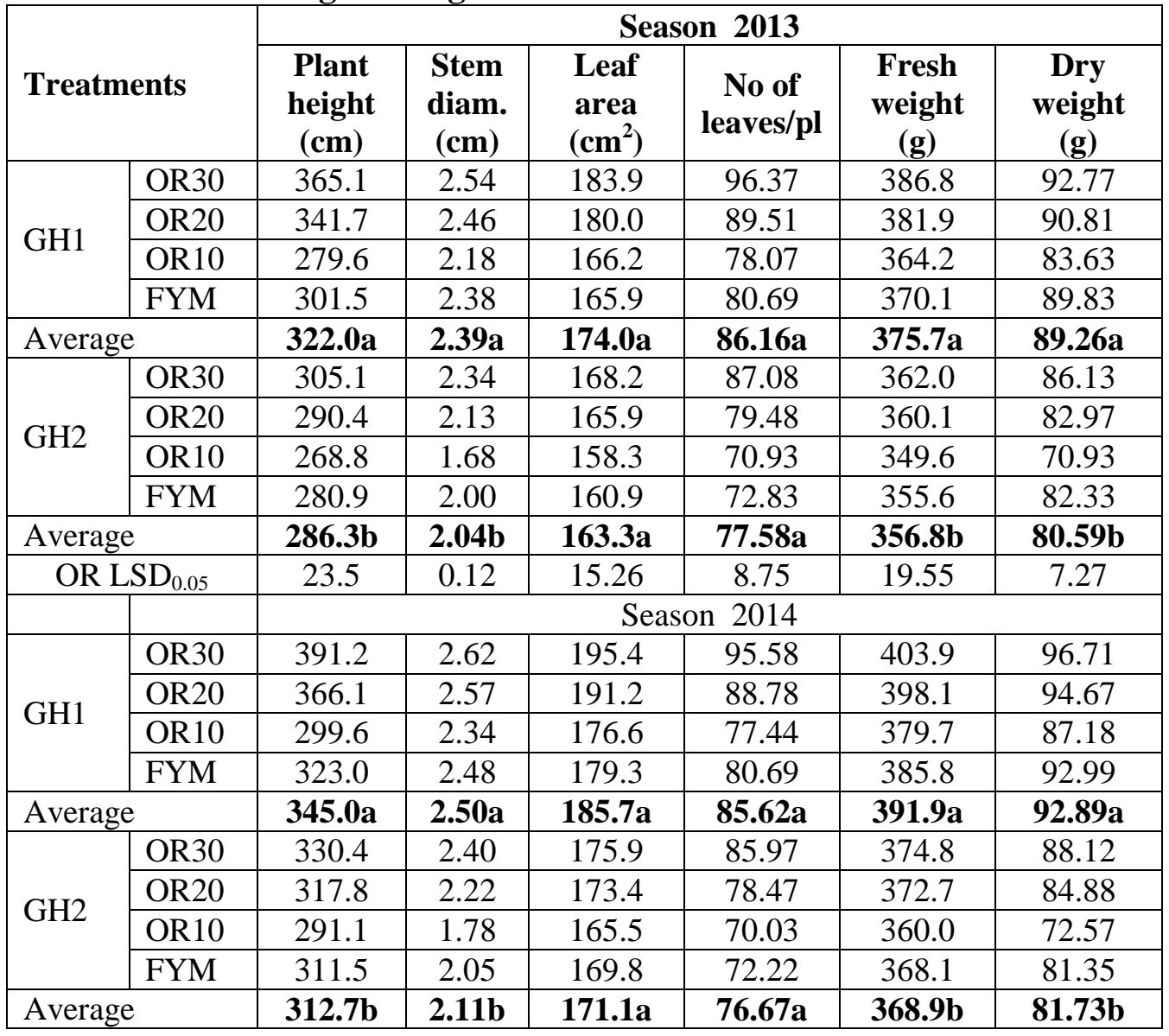


As the solar heating system was elevated the nighttime temperature and maintained the greenhouse $(\mathrm{GH} 1)$ temperature within the optimal level resulting in vigorous vegetative growth. Most plant growth occurs at night. The plants grow better with night time temperature several degrees below daytime temperature. Temperature controls the rate of plant metabolism. When night temperatures are high plants burn more energy in respiration but also have the ability to produce more growth. When night temperatures are lower, growth is slowed but energy lost to respiration is also reduced.

\subsection{Chemical composition of plant foliage.}

Effect of organic fertilizer treatments and macroclimate conditions on NPK uptake was presented in Table (4). Concerning the effect of organic fertilizer treatments on NPK uptake, data of plant leaves analysis presented in Table (4) indicated that by increasing the organic fertilizer quantity, the N, P and $\mathrm{K}$ content in plant leaves was increased in both seasons. Results of plant analysis also, showed that plants supplied with $30 \mathrm{~m}^{3} /$ fed removed higher quantities of $\mathrm{N}, \mathrm{P}$ and $\mathrm{K}$ elements than that of plants supplied with other organic applications or farm yard manure. Iron and manganese content was significantly increased by increasing the rate of organic fertilizer in both seasons. However, Plants supplied with 10 $\mathrm{m}^{3} /$ fed of dried biogas residue or FYM had the lowest N, P and K uptake as compared with the other treatments and were not significantly differed. Data demonstrated in Table (4) explained also, that nitrogen phosphorus and potassium uptake was significantly affected by macroclimate variations in both greenhouses in both 2013 and 2014 seasons. While, the nitrogen increase was not significant in the first season only. Iron and manganese content was significantly increased by maintaining the greenhouse in the optimal temperature level in both seasons.

\subsection{Fruit physical characteristics.}

Effect of organic fertilizer treatments and macroclimate conditions on quality of tomato fruits was demonstrated in Table (5). Result demonstrated in the table displayed out the physical characteristics of tomato fruit in both seasons. Results proved that increasing organic fertilizer rate significantly increased fruit length, fruit diameter and flesh thickness for both greenhouses in both 2013 and 2014 seasons. On the other hand, that increase was not significant for length/diameter ratio character in both seasons. 
Table (4). Effect of macroclimate conditions and organic fertilizer applications on NPK uptake in 2013 and 2014 seasons.

\begin{tabular}{|c|c|c|c|c|c|c|c|c|c|c|c|}
\hline & \multirow{2}{*}{ OR } & \multicolumn{5}{|c|}{2013 season } & \multicolumn{5}{|c|}{2014 season } \\
\hline & & N\% & $\mathbf{P \%}$ & $\mathbf{K}$ & $\mathbf{F e}$ & Mn & N\% & $\mathbf{P \%}$ & $\mathbf{K}$ & $\mathbf{F e}$ & Mn \\
\hline \multirow{4}{*}{ GH1 } & OR30 & 3.82 & 0.55 & 5.65 & 333 & 40.18 & 3.80 & 0.54 & 5.40 & 329.3 & 41.24 \\
\hline & OR20 & 3.70 & 0.51 & 5.52 & 312 & 36.59 & 3.68 & 0.50 & 5.27 & 308.6 & 37.55 \\
\hline & OR10 & 3.56 & 0.45 & 5.26 & 295 & 31.36 & 3.57 & 0.45 & 5.02 & 291.2 & 32.19 \\
\hline & FYM & 3.47 & 0.48 & 5.33 & 285 & 32.34 & 3.54 & 0.47 & 5.16 & 292.6 & 32.51 \\
\hline \multicolumn{2}{|c|}{ Average } & $3.63 a$ & $0.50 a$ & $5.44 a$ & $306 a$ & $35.12 \mathrm{a}$ & $3.65 a$ & $0.49 a$ & $5.21 \mathrm{a}$ & $305.4 a$ & $35.87 a$ \\
\hline \multirow{4}{*}{$\mathrm{GH} 2$} & OR30 & 3.45 & 0.51 & 5.32 & 304 & 34.47 & 3.49 & 0.50 & 5.18 & 280.4 & 38.36 \\
\hline & OR20 & 3.35 & 0.46 & 5.19 & 286 & 29.45 & 3.40 & 0.45 & 5.05 & 267.1 & 33.41 \\
\hline & OR10 & 3.27 & 0.38 & 5.02 & 266 & 27.26 & 3.34 & 0.38 & 4.89 & 244.9 & 30.34 \\
\hline & FYM & 3.15 & 0.41 & 5.08 & 272 & 26.95 & 3.46 & 0.48 & 5.14 & 282.4 & 37.66 \\
\hline \multicolumn{2}{|c|}{ Average } & $3.30 \mathrm{a}$ & $0.44 b$ & $5.15 b$ & $282 b$ & $29.53 b$ & $3.42 \mathrm{~b}$ & $0.45 b$ & $5.06 \mathrm{~b}$ & $268.7 b$ & 34.94b \\
\hline \multicolumn{2}{|c|}{ OR $\mathrm{LSD}_{0.05}$} & 0.16 & 0.08 & 0.14 & 10.44 & 1.51 & 0.11 & 0.09 & 0.20 & 11.07 & 1.31 \\
\hline
\end{tabular}


Table (5). Effect of macroclimate conditions and organic fertilizer applications on quality of tomato fruits in 2013 and 2014 seasons.

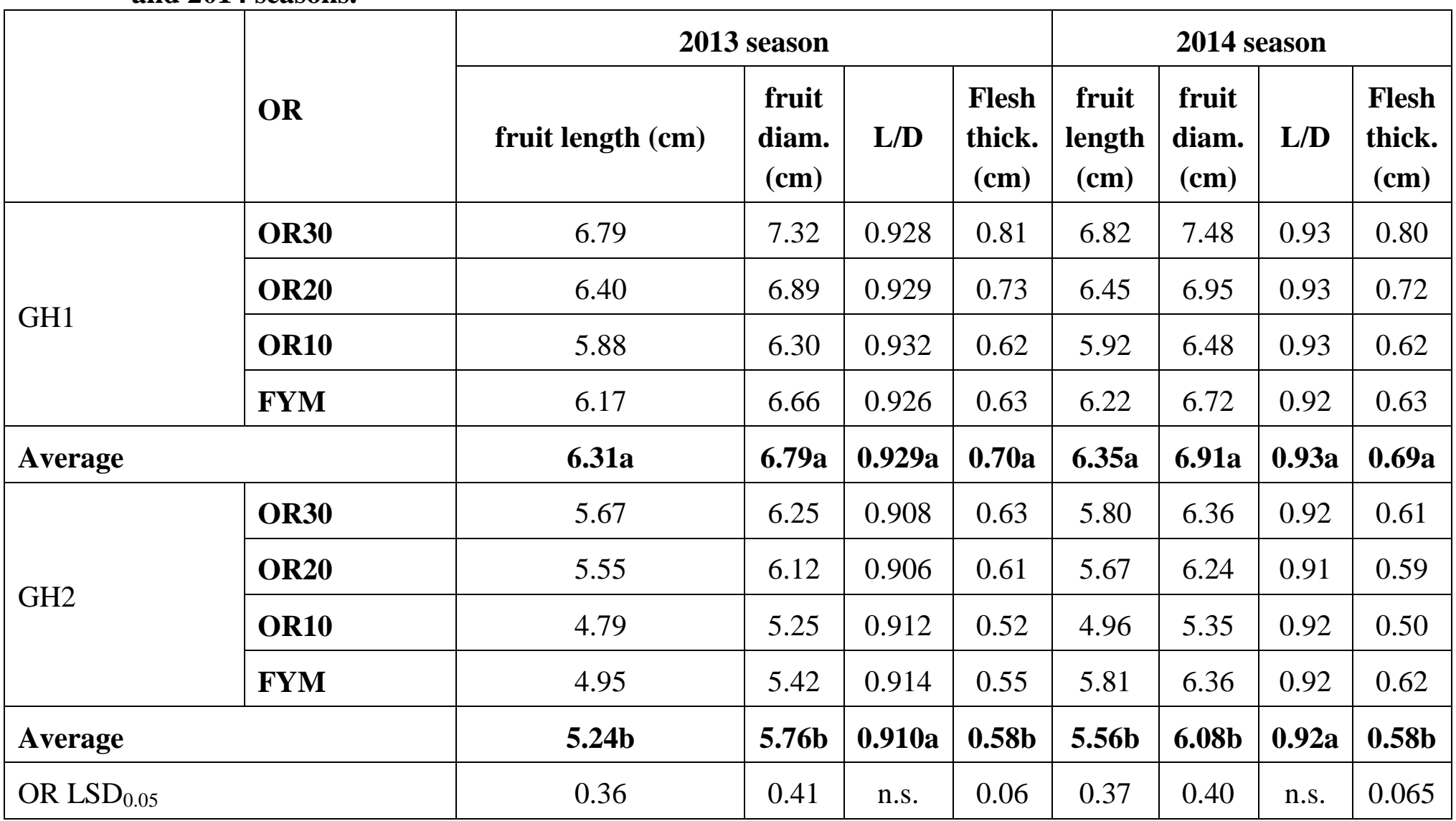


The results in the same table also, confirmed that all studied characters were significantly differed by enhancing the nighttime temperature of GH1 greenhouse than $\mathrm{GH} 2$ greenhouse except for length/diameter ratio in both 2013 and 2014 seasons. These results were in line with Pearce et al., (1993) they indicated that the growth rates of fruit were found to be positively related to fruit temperature between 10 and $30{ }^{\circ} \mathrm{C}$, with an increase in fruit diameter of $5 \mathrm{~mm} \mathrm{~h}^{-1}{ }^{\circ} \mathrm{C}^{-1}$. Saeed et al., (2007) also, stated that tomato succeeded well under tropical and subtropical regions. It can grow vigorously and is highly productive within the temperature range of $18-28^{\circ} \mathrm{C}$.

\subsection{Fruit chemical characteristics.}

Effect of organic fertilizer treatments and macroclimate conditions on quality of tomato fruits in 2013 and 2014 seasons was presented in Table (6). The illustrated results of fruit chemical characteristics exhibited that all the studied characters such as; ascorbic acid, acidity, total chlorophyll, dry matter and total soluble solids were significantly increased by increasing the organic fertilizer rate in both seasons in both greenhouses. It was observed that the acidity character was higher in greenhouse $\mathrm{GH} 2$ than greenhouse $\mathrm{GH} 2$. The results also, illustrated that ascorbic acid, acidity and total soluble solids was significantly enhanced by enhancing the macroclimate conditions inside the GH1 greenhouse, whereas the dry matter and total chlorophyll were not differed in both greenhouses in 2013 and 2014 seasons.

\subsection{Early and total fruit yield and its components.}

Effect of organic fertilizer treatments and macroclimate conditions on early and total fruit yield and yield components were demonstrated in Table (7). The results demonstrated in Table (7) gave us an idea about the response of the yield and its components according to increasing the levels of organic fertilizer. Early yield, number of fruit per plant, fruit weight, total yield per plant and total yield per feddan were significantly increased by increasing the organic fertilizer rate in both 2013 and 2014 seasons.

For the heated greenhouse (GH1), the percentages increase in early yield, number of fruit per plant, fruit weight, total yield per plant and total yield per feddan over those of farm yard manure were 28.64, 13.04, 6.89, 20.84 and $20.84 \%$, respectively for $30 \mathrm{~m}^{3} /$ fed dried biogas residue, while they were $11.27,10.27,4.83,15.67$ and $15.67 \%$ for $20 \mathrm{~m}^{3} / \mathrm{fed}$, whereas, the percentages decreases in these characters for $10 \mathrm{~m}^{3} / \mathrm{fed}$ dried biogas residue, lower than those of farm yard manure were $6.69,8.74,2.38,11.35$ and $11.35 \%$, respectively in 2013 season. 
Table (6). Effect of macroclimate conditions and organic fertilizer applications on quality of tomato fruits in 2013 and 2014 seasons.

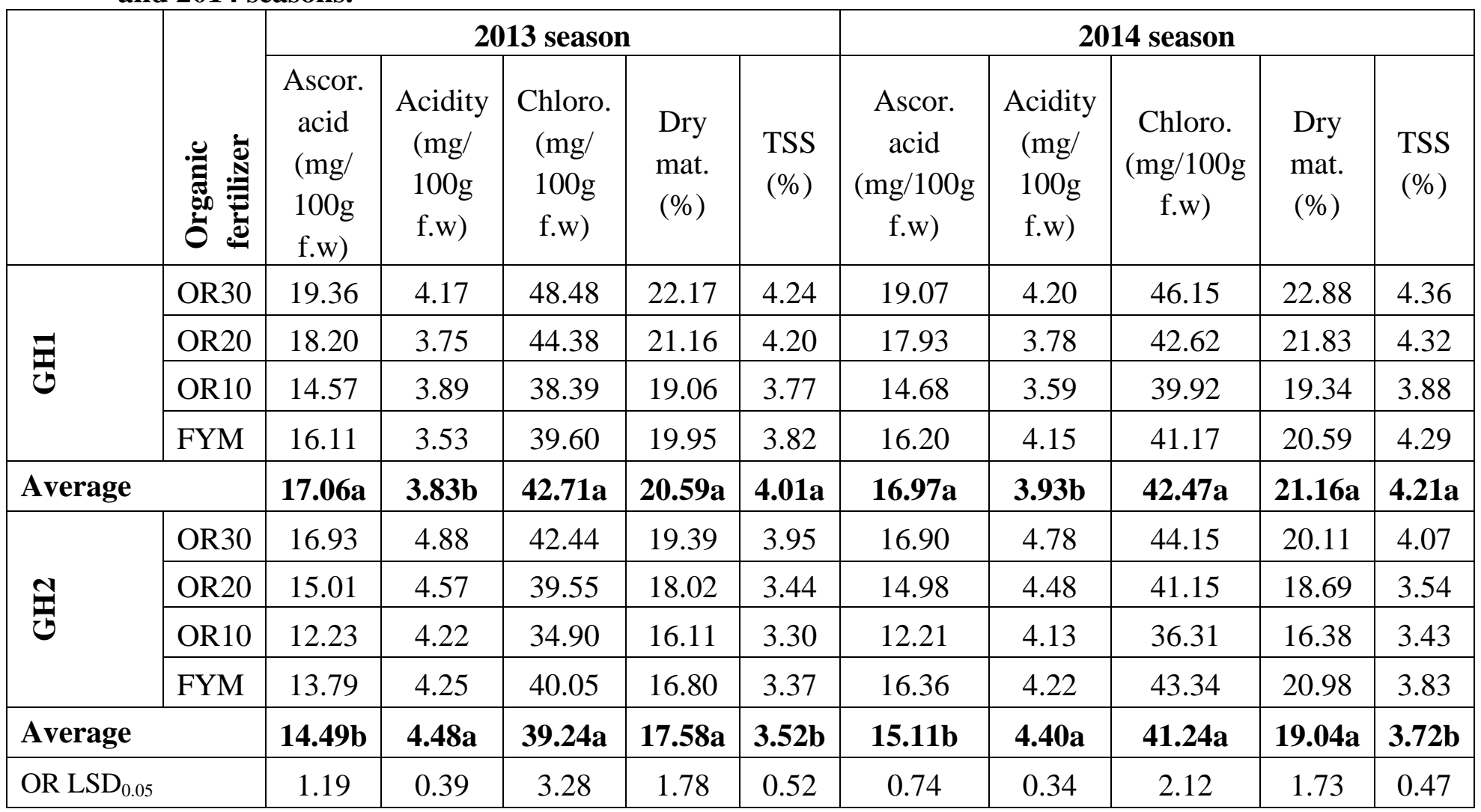


Table (7). Effect of macroclimate conditions and organic fertilizer levels on early, total fruit yield and yield

\begin{tabular}{|c|c|c|c|c|c|c|c|c|c|c|c|}
\hline & \multirow[b]{2}{*}{ OR } & \multicolumn{5}{|c|}{2013 season } & \multicolumn{5}{|c|}{2014 season } \\
\hline & & $\begin{array}{c}\text { Early } \\
\text { yield } \\
(\mathrm{kg} / \mathrm{pl})\end{array}$ & $\begin{array}{c}\text { No. } \\
\text { fruit/PI }\end{array}$ & $\begin{array}{c}\text { Fruit } \\
\text { weight } \\
\text { (g) }\end{array}$ & $\begin{array}{c}\text { Yield/ } \\
\text { Plant } \\
\text { (kg) }\end{array}$ & $\begin{array}{c}\text { Yield/ } \\
\text { fed } \\
\text { (ton/ } \\
\text { fed) }\end{array}$ & $\begin{array}{c}\text { Early } \\
\text { yield } \\
(\mathrm{kg} / \mathrm{pl})\end{array}$ & $\begin{array}{c}\text { No. } \\
\text { fruit/PI }\end{array}$ & $\begin{array}{c}\text { Fruit } \\
\text { weight } \\
\text { (g) }\end{array}$ & $\begin{array}{c}\text { Yield/ } \\
\text { Plant } \\
\text { (kg) }\end{array}$ & $\begin{array}{c}\text { Yield/ } \\
\text { fed } \\
\text { (ton/ } \\
\text { fed) } \\
\end{array}$ \\
\hline \multirow{4}{*}{ GH1 } & OR30 & 1.80 & 75.12 & 166.4 & 12.51 & 51.27 & 1.86 & 78.36 & 169.04 & 13.25 & 54.33 \\
\hline & OR20 & 1.56 & 73.28 & 163.2 & 11.97 & 49.08 & 1.69 & 77.72 & 165.77 & 12.90 & 52.88 \\
\hline & OR10 & 1.49 & 72.26 & 159.4 & 11.52 & 47.25 & 1.37 & 65.30 & 154.17 & 10.07 & 41.29 \\
\hline & FYM & 1.40 & 66.45 & 155.7 & 10.35 & 42.43 & 1.49 & 70.48 & 158.14 & 11.15 & 45.71 \\
\hline \multicolumn{2}{|c|}{ Average } & $1.56 \mathrm{a}$ & $71.78 \mathrm{a}$ & 161.2a & $11.59 \mathrm{a}$ & $47.51 \mathrm{a}$ & $1.60 \mathrm{a}$ & $72.97 \mathrm{a}$ & 161.8a & $11.84 \mathrm{a}$ & $48.55 \mathrm{a}$ \\
\hline \multirow{4}{*}{ GH2 } & OR30 & 1.39 & 69.41 & 148.4 & 10.30 & 42.22 & 1.52 & 70.93 & 151.82 & 10.76 & 44.13 \\
\hline & OR20 & 1.33 & 64.23 & 146.4 & 9.41 & 38.58 & 1.45 & 65.64 & 149.74 & 9.84 & 40.33 \\
\hline & OR10 & 1.20 & 51.18 & 139.4 & 7.13 & 29.24 & 1.25 & 55.51 & 142.56 & 7.91 & 32.44 \\
\hline & FYM & 1.23 & 59.69 & 137.0 & 8.20 & 33.61 & 1.30 & 60.99 & 143.40 & 8.76 & 35.93 \\
\hline \multicolumn{2}{|c|}{ Average } & $1.29 \mathrm{~b}$ & $61.13 \mathrm{~b}$ & $142.8 \mathrm{~b}$ & $8.76 \mathrm{~b}$ & $35.91 \mathrm{~b}$ & $1.38 \mathrm{~b}$ & $63.27 \mathrm{~b}$ & $146.9 \mathrm{~b}$ & 9.32b & $38.21 \mathrm{~b}$ \\
\hline \multicolumn{2}{|c|}{$\mathrm{OR} \mathrm{LSD}_{0.05}$} & 0.11 & 3.80 & 12.66 & 1.34 & 5.51 & 0.14 & 3.22 & 12.11 & 1.27 & 5.21 \\
\hline
\end{tabular}


For the unheated greenhouse (GH2), the percentages increase in early yield, number of fruit per plant, fruit weight, total yield per plant and total yield per feddan over those of farm yard manure were 13.18, 16.29, 8.30, 25.52 and $25.52 \%$, respectively for $30 \mathrm{~m}^{3} / \mathrm{fed}$ dried biogas residue, while they were $8.01,7.61,6.82,14.78$ and $14.78 \%$ for $20 \mathrm{~m}^{3} / \mathrm{fed}$, whereas, the percentages decreases in these characters for $10 \mathrm{~m}^{3} /$ fed dried biogas residue, lower than those of farm yard manure were 2.58, 14.26, 1.69, 12.99 and $12.99 \%$ in same season. Furthermore, in the second season 2014, for the heated greenhouse (GH1), the percentages increase in early yield, number of fruit per plant, fruit weight, total yield per plant and total yield per feddan over those of farm yard manure were $24.87,11.18,6.89,18.86$ and $18.86 \%$, respectively for 30 $\mathrm{m}^{3} /$ fed dried biogas residue, while they were $13.47,10.27,4.83,15.67$ and $15.67 \%$ for $20 \mathrm{~m}^{3} / \mathrm{fed}$, whereas, the percentages decreases in these characters for $10 \mathrm{~m}^{3} /$ fed dried biogas residue, lower than those of farm yard manure were $7.74,7.36,2.51,9.68$ and $9.68 \%$, respectively. For the unheated greenhouse (GH2), the percentages increase in early yield, number of fruit per plant, fruit weight, total yield per plant and total yield per feddan over those of farm yard manure were 17.18, 16.29, 5.87, 22.84 and 22.84\%, respectively for $30 \mathrm{~m}^{3} / \mathrm{fed}$ dried biogas residue, while they were $12.06,7.61$, $4.42,12.24$ and $12.24 \%$ for $20 \mathrm{~m}^{3} / \mathrm{fed}$, whereas, the percentages decreases in these characters for $10 \mathrm{~m}^{3} / \mathrm{fed}$ dried biogas residue, lower than those of farm yard manure were $3.40,8.99,0.59,9.70$ and $9.70 \%$ in same season. These results were in agreement with Midan (1995) who studied FYM and biogas residue application and found the superiority of biogas organic fertilizer on plant growth as compared with FYM and Chicken manure. Also, Nguyen et al. (2015) mentioned that the applications of organic fertilizers enhanced the leaf area and average fruit weight and yield.

The data also, indicated that all the investigated characters such as; early yield, number of fruit per plant, fruit weight, total yield per plant and total yield per feddan positively improved due to enhancing the macroclimate conditions of GH1 greenhouse in both seasons. The percentages increase for GH1 greenhouse over GH2 greenhouse in early yield, number of fruit per plant, fruit weight, yield per plant and total yield per feddan were 21.32, $17.42,12.87,32.28$ and $32.28 \%$, respectively in 2013 season, while they were $16.06,15.33,10.14,27.08$ and $27.08 \%$, respectively in 2014 season. Nemours investigators reported low yields in lower temperature regime for 
glasshouse tomato, Jones (2007) found that tomato yields are primarily affected by the climate conditions with highest yields belonging to greenhouse in which has moderate air temperature. Also, Nguyen et al. (2015) mentioned that the applications of organic fertilizers enhanced the leaf area and average fruit weight and yield of tomato fruit. These results is in harmony with those obtained by Islam (2011) who reported that number of fruits/plant, individual fruit weight and fruit yield/plant significantly decreased at $32^{\circ} \mathrm{C}$ temperature at pre-flowering and flowering stages. The optimum fruit growth and development occur when night temperature is between 15 and $20^{\circ} \mathrm{C}$ and the day temperature at about $25^{\circ} \mathrm{C}$ (Kalloo, 1985).

\section{CONCLUSION}

Result of this work showed that the application of $30 \mathrm{~m}^{3} / \mathrm{fed}$ significantly increased the vegetative growth, yield and its quality of tomato fruit. Meanwhile, there were no significant differences between the application of 30 and $20 \mathrm{~m}^{3} / \mathrm{fed}$ applications in most studied characters. The result showed also, that farm yard manure application at rate of $20 \mathrm{~m}^{3} /$ fed surpassed the 10 $\mathrm{m}^{3} /$ fed application of dried biogas digester residue with no significant differences. For the heated greenhouse (GH1), the percentages increase in early yield, number of fruit per plant, fruit weight, total yield per plant and total yield per feddan were $28.64,13.04,6.89,20.84$ and $20.84 \%$, respectively for dried biogas residue of $30 \mathrm{~m}^{3} /$ fed over those of farm yard manure, respectively in 2013 season. For the unheated greenhouse (GH2), the percentages increase in early yield, number of fruit per plant, fruit weight, total yield per plant and total yield per feddan over those of farm yard manure were $13.18,16.29,8.30,25.52$ and $25.52 \%$, respectively for $30 \mathrm{~m}^{3} /$ fed dried biogas residue in same season. Whereas, in the second season 2014, for the heated greenhouse (GH1), the percentages increase in early yield, number of fruit per plant, fruit weight, total yield per plant and total yield per feddan over those of farm yard manure were $24.87,11.18,6.89,18.86$ and $18.86 \%$, respectively for $30 \mathrm{~m}^{3} / \mathrm{fed}$ dried biogas residue, respectively. For the unheated greenhouse (GH2), the percentages increase in early yield, number of fruit per plant, fruit weight, total yield per plant and total yield per feddan over those of farm yard manure were 17.18, 16.29, 5.87, 22.84 and 22.84\%, respectively for $30 \mathrm{~m}^{3} / \mathrm{fed}$ dried biogas residues in same season. It can be concluded that application with $30 \mathrm{~m}^{3} /$ fed dried biogas residues recorded the 
best treatment to obtain the highest vegetative growth, yield and quality of tomato plants.

Concerning effect of the microclimatic conditions of (GH1) was at and around the optimal level for the tomato crop, resulting in increase the growth, development, and productivity of crop. The data also, indicated that all the investigated characters such as; early yield, number of fruit per plant, fruit weight, total yield per plant and total yield per feddan positively improved due to enhancing the macroclimate conditions of $\mathrm{GH} 1$ greenhouse in both seasons. The percentages increase for $\mathrm{GH} 1$ greenhouse over $\mathrm{GH} 2$ greenhouse in early yield, number of fruit per plant, fruit weight, yield per plant and total yield per feddan were $21.32,17.42,12.87,32.28$ and $32.28 \%$, respectively in 2013 season, while they were 16.06, 15.33, 10.14, 27.08 and $27.08 \%$, respectively in 2014 season.

\section{REFERENCES}

A.O.A.C. (1990) Association of Official Analysis Chemical. Official Methods of Analysis $15^{\text {th }}$ Ed. Washington DC, USA.

A.O.C.A. (1980) Association of official analytical Chemists method of analysis $13^{\text {th }}$ Ed Washington. D. C.

Abd El-Mageed, A.H.A. and N. Gruda (2009). Performance of Different Tomato Genotypes in the Arid Tropics of Sudan during the Summer Season. II. Generative Development Journal of Agriculture and Rural Development in the Tropics and Subtropics Volume 110, No. 2, pages $147-154$

Abdalla, A.M., Fatma A. Rizk and Safia M. Adam, (2001). The productivity of pepper plants as influenced by some bio-fertilizer treatments under plastic house conditions. Bull. Fac. Agric., Cairo Univ., 52: 625-640.

Abou-Hussein, S. D., I. EL- Oksh, T. EL- Shorbagy and U. A. ELBahiry, 2002. Effect of chicken manure, compost and biofertilizers on vegetative growth, tuber characteristics and yield of potato crop. Egyp. J. Hort., 29:135-149.

Adams, S.R., K.E. Cockshull and C.R.J. Cave (2002). Effect of temperature on the growth and development of tomato fruits. Annals Bot. 88, 869-877. 
Adil, A.H.; Gruda, N. and Geyer, B. (2004): Effects of temperature and grafting on the growth and development of tomato plants under controlled conditions. Rural poverty reduction through research for development and transformation, berlin, October 5-7, 2004.

Aminifard, M. H., H. Aroiee, H. Nemati, M. Azizi, and M. Khayyat (2012). Effect of nnitrogen fertilizers on vegetative and reproductive growth of pepper plants under field conditions. J. Plant Nutr., 35: 235242.

Cesare, L. F. D., C. Migliori, D. Viscardi and M. Parisi (2010). Quality of tomato fertilized with nitrogen and phosphorous. Italian J. Food Sci., 2(22):186-191.

Chapagain, B. P. and Z. Wiesman (2004). Effect of nutri-vant-peak foliar spray on plant development, yield, and fruit quality in greenhouse tomatoes. Scientia Horticulturae, 102: 177-188.

Chiappmann, H. D. and P. F. Pratt (1981) Method of Analysis for Soils Plant and Water .Agric. Sci. 19, 183-187.

Çolpan, E., Zengin, M. and Özbahçe, A. 2013.The Effects of Potassium on the Yield and Fruit Quality Components of Stick Tomato. Hort. Environ. Biotechnol., 54(1): 20-28.

Dursun, A., M. Turan, M. Ekinci, A. Gunes, N. Ataoglu, A. Esringu, and E. Yildirim (2009). Effects of boron fertilizer on tomato, pepper, and cucumber yields and chemical composition. Commun. Soil Sci. Plan., 41:1576-1593.

EL -Gamal, S. M. A. and S. A. Hammad, 2005. Response of Helianthus tuberosus L. to organic and bio - organic fertilizers. Arab Univ. J . Agric. Sci., Ain shams Univ., Cairo. Egypt. 13 (3) : 609 - 623.

EL-Araby, S. M., 2004. Effect of biofertilization under nitrogen fertilization rates on growth, yield and chemical constituents of Jerusalem artichoke tubers. J. of the Advances in Agric. Researches. Fac. Agric. Saba Basha Alex. Univ. 9 (1):55 - 67.

El-Shimi, Nahed (1998): Comparative studies of organic manures and chemical fertilizers on yield and quality of cabbage. M.Sc Thesis Fac. Agric. Moshtohor, Zagazig Univ., Cairo, Egypt. 
FAO, (1981). Crop Production Levels and Fertilizer Use. Food and Agriculture Organization of the United Nation, Rome, PP.3-22

Hamed N. M. (2008). Response of jerusalem artichoke plants to some bio and organic fertilization treatments in the newly reclaimed lands. $\mathrm{PhD}$. Thesis, Fac. Agric. Ain Shams Univ.

Heeb, A., B. Lundegårdh, G. Savage and T. Ericsson (2006). Impact of organic and inorganic fertilizers on yield, taste, and nutritional quality of tomatoes. J. Plant Nutr. Soil Sci., 169: 535-541.

Islam, M.T. (2011). Effect of temperature on photosynthesis, yield attributes and yield of tomato genotypes. Int. J. Expt. Agric. 2(1):8-11, (January 2011)

Jones, Jr B. (2007). Tomato Plant Culture: In the Field, Greenhouse, and Home Garden, $2^{\text {nd }}$ Boca Raton, FL: CRC Press. Taylor \& Francis Group, LLC.

Joshi, R. and A. P. Vig (2010). Effect of vermicompost on growth, yield and quality of tomatoes. African Journal of Basic \& Applied Sciences 2 (34): 117-123, 2010. ISSN 2079-2034. IDOSI Publications, 2010. Available at: http://www.idosi.org/ajbas/ajbas2\%283- 4\%2910/10.pdf

Junior, J. L. R., J. A. G. Neto, and L. V. S. Sacramento, (2013). Evaluation of different foliar fertilizers on the crop production of saccharide cane. J. Plant Nutr., 36: 459-469.

Kalloo, D. (1985). Tomato. Allied Publishers Private Ltd. 13/14 Asaf Ali Road, New Delhi-110002. p 172-202.

Kobryn, J. and E. Hallmann (2005). The effect of nitrogen fertilization on the quality of three tomato types cultivated on rockwool. Acta Hort., 691: 341-348.

López, A.; D. L. Valera; F. D. Molina-Aiz; and A. Peña (2012) "Sonic anemometry to evaluate airflow characteristics and temperature distribution in empty Mediterranean greenhouses equipped with padfan and fog systems" Biosyst., Eng. 113: 334-350.

Mervat, A.T., T. Amara and M.S.A. Dahdoh.( 1995). Effect of inoculation with plant growth promoting rhizobacteria on yield and uptake of 
nutrients by wheat grown on sandy soil. Fifth National Congress on Bio Agric. In relation to Environment. Nov., 20 - 21, Cairo, Egypt, pp : 327 -331 .

Midan, S. A. (1995): Response of some promising pepper genotypoes to different cultural treatments. M.Sc Thesis Fac. of Agric. Menofiya Univ. Egypt.

Mikhaeel, F. T.; A. N. Estefanous; S. A. El-Shimi; F. W. Riad (1997): Mycorrhizal fungus, Glomus aggregatum and biogas manure as an integrated control of root-knot nematode in tomato. Bulletin of Fac. of Agric. Cairo. Univ. 48 : 737-748.

Ministry of Agriculture and Land Reclamation (2004). Bulletin No.(902), 2004. Egypt.

Najm, A. A., Haj Seyed Hadi, M. R., Fazeli, F., Taghi Darzi, M. and Shamorady, R. 2010. Effect of Utilization of Organic and Inorganic Nitrogen Source on the Potato Shoots Dry Matter, Leaf Area Index and Plant Height, during Middle Stage of Growth. World Acad. Sci. Engin. Technol., 47: 900 -903.

Nguyen, T. N., L. H. Tang, Y. K. Peng, J. Y. Ni, and Y. N. Chang (2015). Effects of Composite Inorganic, Organic Fertilizer and Foliar Spray of Multi-nutrients on Growth, Yield and Quality of Cherry Tomato. J. Agr. Sci. Tech. (2015) Vol. 17: 1781-1788

Pardossi, A.; P. Giacomet, F.; Malorgio, F. M. Albini; C. Murelli; G. Serra; P. Vernieri; and F. Tognoni (2000) "The influence of growing season on fruit yield and quality of greenhouse melon (Cucumis melo L.) grown in nutrient film technique in a Mediterranean climate" J. Hort. Sci. Biotechn. 75 (4): 488-493.

Pearce, B.D., R.I. Grange and K. Hardwick (1993). The growth of young tomato fruit. II. Environmental influences on glasshouse crops grown in rockwool or nutrient film. J. of HortiSci., 68: 13-23.

Pirkko, R., V. Jaana, G. Artur, and K.Susanna (2003). Effects of different organic fertilization practices and mineral fertilization on potato quality. Biol. Agric. Hortic., 21: 165-194. 
Pressman, E.; Peet, M.M. and Pharr, D.M. (2002): The effect of heat stress on tomato pollen characteristics is associated with changes in carbohydrate concentration in the developing anthers. Annals of Botany 90: 631-636.

Ranganna, S (1979). Manual Analysis of Fruit and Vegetable Product. Tata Magrow Hill Publishing Company Limited New Delhi 634p.

Riahi, A., C. Hdider, M. Sanaa, N. Tarchoun, M. B. Khedere and I. Guezal (2009). Effect of conventional and organic production systems on the yield and quality of field tomato cultivars grown in tunisia. $J$. Sci. Food Agri., 89: 2275-2282.

Rizk, Fatma A., M.R. Shafeek and Y.I. Helmy, 2003. A comparative study between the application of bio and/or mineral fertilizers with squash plant. Egypt. J. Appl. Sci., 18(4A): 257-269.

Saeed, A., Kh. H., A. A. Khan and S. Iqbal (2007). Heat tolerance studies in tomato (Lycopersicon esculentum Mill.). Int. J. Agri. Biol., Vol. 9, No. 4, 649-652, 2007. http://www.fspublishers.org

Santamouris M. et al. (1994) "Passive solar agricultural greenhouses: a worldwide classification and evaluation of technologies and systems used for heating purposes" J. Solar Energy. 53(5):411-426.

Sato, S., Peet MM, and Thomas JF (2000). Physiological factors limit fruit set of tomato (Lycopersicon esculentum Mill.) under chronic, mild heat stress. Plant Cell Environ 23:719-726.

Snedecor, G. W.; and W. G. Cochran (1980) "Statistical Methods" The Iowa State Univeristy Press, Ames, USA, pp. 135-170.

Vollenweider P, Gunthardt-Goerg MS (2005). Diagnosis of abiotic and biotic stress factors using the visible symptoms in foliage. Environ Pollut 137:455-465.

Wang, Y. T., Huang, S., Liu, R. and Jin, J. 2007. Effects of Nitrogen Application on Flavor Composites of Cherry Tomato Fruits. J. Plant Nutr. Soil Sci., 170: 461-468.

Yakout, T.R.; Doaa M. Mostafa and G.D.M. Youssef (2014). Effect of utilizing dried biogas digester residue as an organic-fertilizer with 
mineral and bio-fertilizer on growth and yield of sweet pepper inside greenhouses. Alexandria Science Exchange Journal. Vol. 35 (4) October- December 2014: 325-333.

Yang, L. J., H. Qu, Y. L. Zhang and F. S. Li (2012). Effects of partial rootzone irrigation on physiology, fruit yield and quality and water use efficiency of tomato under different calcium levels. Agric. Water Manag., 104: 89- 94.

Youssef, G.D.M. (2007) "Thermal storage system for greenhouse energy conservation" Ph.D., Agric. Eng. Depart., Faculty of Agriculture, Alexandria University

Youssef, G.D.M. and S.A.M. Moussa (2015). Investigation and Utilization of Solar Energy for Heating Greenhouse Sweet Melon during Winter Season. Alex. J. of Agric. Res., Alexandria Univ., Vol. 60 (3):53 -63, August. 2015.

Youssef, G.D.M., and Yakout, T.R. (2015). Effect of Externally Mounted Shading Screen on Microclimatic Conditions of Greenhouse Cantaloupe Crop Equipped with Evaporative Cooling System. J. Soil Sci and Agric. Eng., Mansoura Univ., 6 (5): 667-685., 2015.

Youssef, G.D.M., Yakout, T.R. and Doaa, M. Mostafa (2015). Improving Performance of the Evaporative Cooling System inside the Greenhouses and its Effect on Tomato Productivity. Alexandria Science Exchange Journal. Vol. 36 (1) January- March 2015: 80 -94.

Zafar, M., M. K. Abbasi, A. Khaliq and Z. Rehman (2011). Effect of combining organic materials with inorganic phosphorus sources on growth, yield, energy content and phosphorus uptake in maize at rawalakot azad jammu and kashmir, Pakistan. Archiv. Appl. Sci. Res., 3(2): 199-212.

Zaller J. G. (2006). Foliar Spraying of Vermicompost Extracts: Effects on fruit quality and indications of tate-blight suppression of field-grown tomatoes. Biol. Agric. Hortic., 24: 165-180.

Zhang H. C., Duan, X. X. and Liao, H. (2010). Fertilizer Application Manual. China agriculture Press, China, PP.1- 4. 


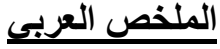

\section{تأثير تدفئة الصوبة ليلا بالطاقة الثمسية والتسميد العضوي على إنتاجية محصول الطماطم}

\section{طارق ياقوت رمضان' و سامى جمعه حميده ' '}

أجريت تجربة بمحطة بحوث البساتين بالصبحية، الإسكندرية، مصر بغرض دراسة تأثثر استخدام

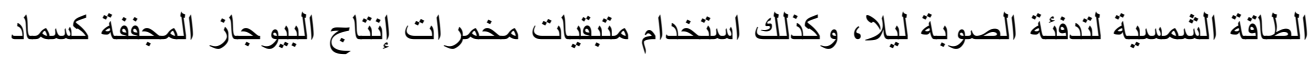

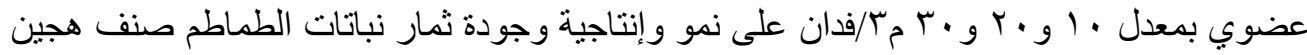

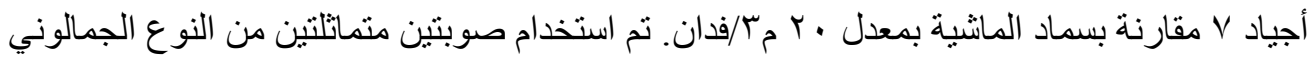

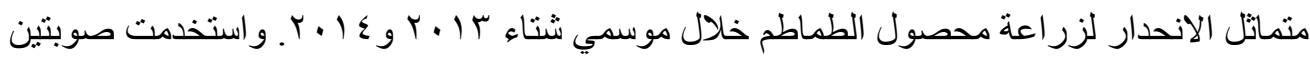
زر اعيتين تختلف كل منهما عن الأخرى فى درجة الحرارة وفى طريقة التحكم فى تهويتها. فكانت

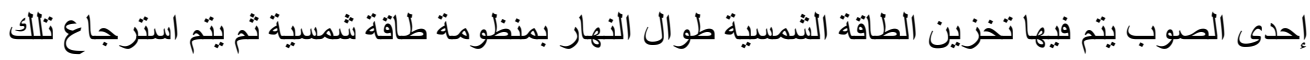
الطاقة لتدفئتها ليلاً ، و أما الأخرى يتحكم في تهويتها ميكانيكيا نهار ا بدون تدفئة ليلية كصوبة مقارنة.

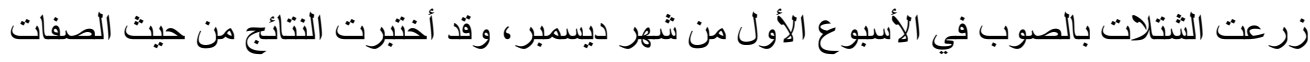
الخضرية و المحصول وجودة الثمار الناتجة. وكانت أهم النتائج المتحصل علئل عليها كما يلي: -

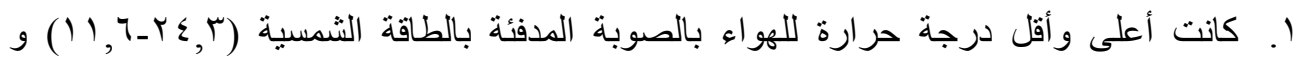

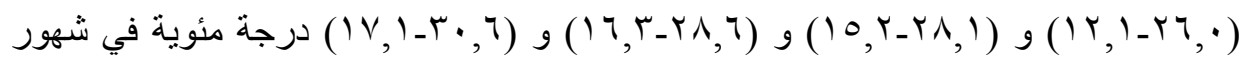

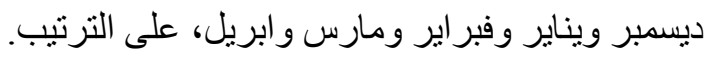

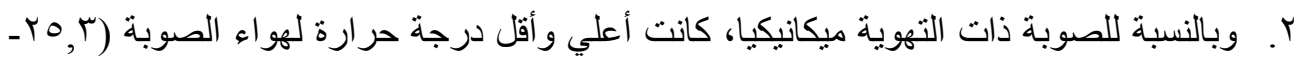

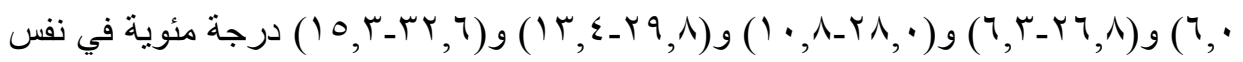
الثهور بالترتيب.

ب. بالنسبة لتأثير التسميد العضوي على نباتات الطماطم، أظهرت النتائج انه بزيادة مستويات

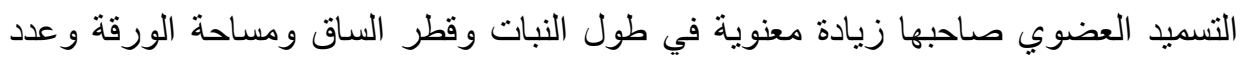

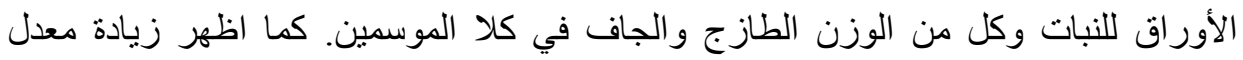

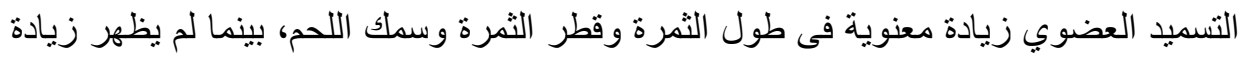

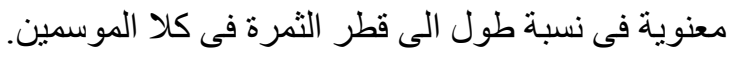
ع. أظهرت النتائج أن معدل • م مب/فدان من سماد البيوجاز المجفف أعطي نموا خضريا أكبر

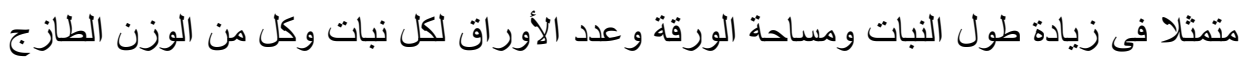
والجاف وقطر الساق مقارنة بباقي المستويات أو سماد الماشية في كلا الموسمين.

'باحث، قسم بحوث الزراعة المحمية ـمعهد بحوث البساتين - مركز البحوث الزراعية ـ الجيزة. ץ باحث، قسم بحوث القوى والطاقة ـمعه بحوث الهندسة الزراعية ـ مركز البحوث الزراعية ـالجيزة. 


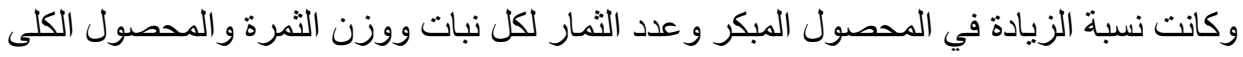

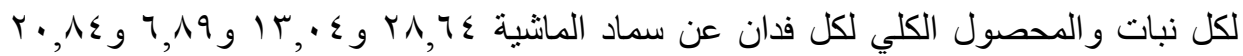

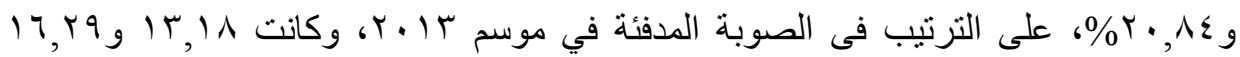

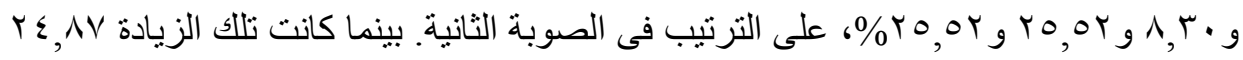

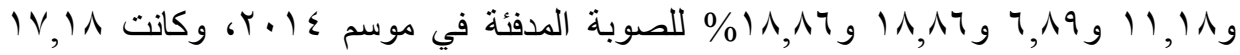

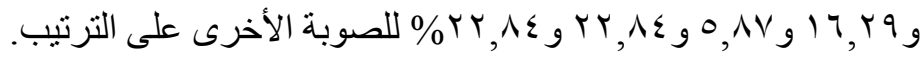

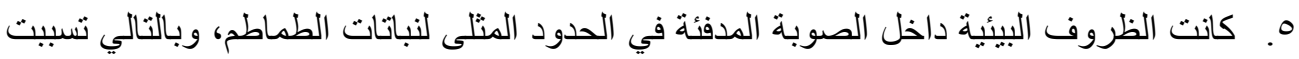

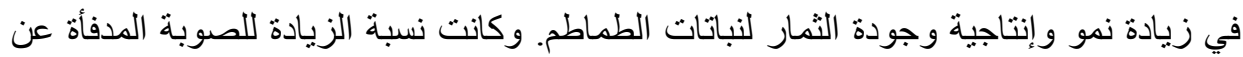

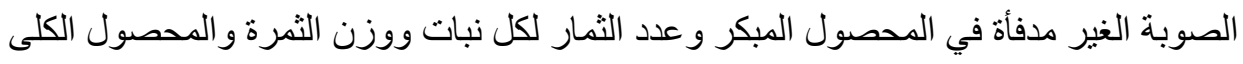

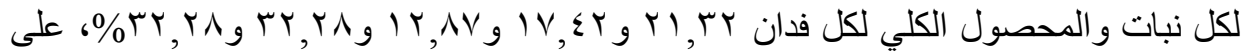

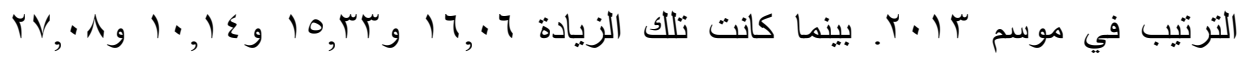

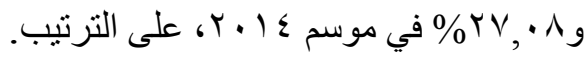

